\title{
Meso-fauna foraging on seagrass pollen may serve in marine zoophilous pollination
}

\author{
Brigitta I. van Tussenbroek ${ }^{1, *}$, L. Veronica Monroy-Velazquez ${ }^{1}$, Vivianne Solis-Weiss ${ }^{2}$ \\ ${ }^{1}$ Unidad Académica de Sistemas Arrecifales-Puerto Morelos, Instituto de Ciencias del Mar y Limnología, \\ Universidad Nacional Autónoma de México, Apdo. Postal 1152, 77500 Cancún, Quintana Roo, Mexico \\ ${ }^{2}$ Instituto de Ciencias del Mar y Limnología, Universidad Nacional Autónoma de México, Circuito Exterior, \\ Ciudad Universitaria, Del. Coyoacán, 04510 México DF, Mexico
}

\begin{abstract}
We investigated meso-faunal invertebrates visiting male and female flowers of the seagrass Thalassia testudinum at night during May to June 2009, 2011 and 2012, in Puerto Morelos reef lagoon, Mexican Caribbean. By means of video recordings, we established that more crustaceans visited male flowers bearing pollen than those without pollen grains. Foraging on pollen was observed on several occasions. On 76 flowers, we found 252 specimens belonging to 37 families and 57 species of crustaceans (Classes Maxillopoda, Ostracoda and Malacostraca), of which 15 were new records for the region. Annelids (mainly polychaetes) were less abundant (60 specimens) and less diverse (13 species), and they exhibited no obvious differences in their visits to male flowers with or without pollen. Negative consequences for seagrass reproductive success by the consumption of pollen were most likely insignificant, because the quantities of removed pollen were very small. However, many crustaceans and polychaetes had pollen embedded in mucilage attached to their body parts after visiting a male flower with pollen. Thus, these invertebrates may serve as pollinators of $T$. testudinum when visiting female flowers.
\end{abstract}

KEY WORDS: Meso-grazer · Crustacea · Polychaeta • Seagrass

Resale or republication not permitted withou written consent of the publisher

\section{INTRODUCTION}

Seagrass beds throughout the world's coastal regions harbour dense populations of small invertebrates (Orth \& van Montfrans 1984, Klumpp et al. 1989,

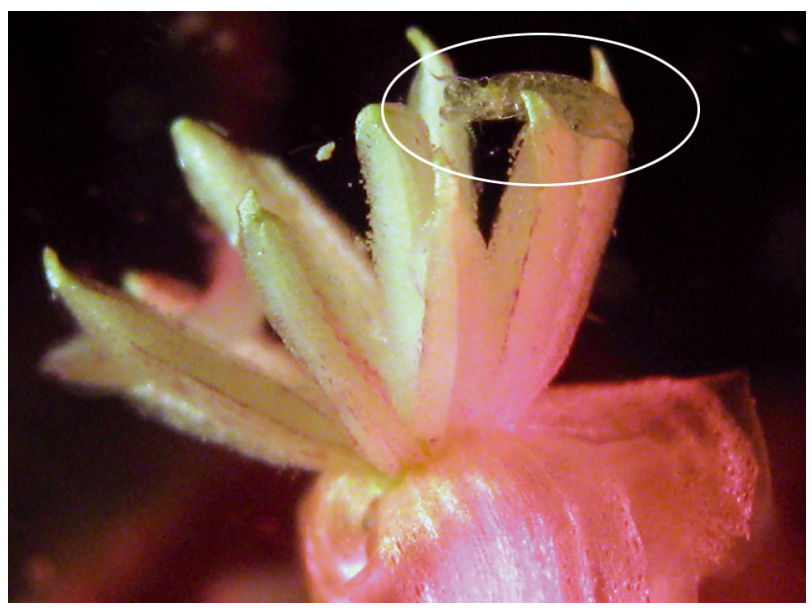

Gamarid amphipod feeding on pollen or mucilage of a male flower of the seagrass Thalassia testudinum at night.

Photo: Brigitta I. van Tussenbroek

Jernakoff et al. 1996) which feed on fresh leaf tissue or detritus of the seagrasses (Nienhuis \& Van Ierland 1978, Kitting 1984). These invertebrate meso-grazers play an important role in seagrass ecosystems because they control the algal epiphyton (Howard 1987, Jernakoff et al. 1996, Duffy \& Hay 2000) and serve as vehicles for energy transfer to higher consumer levels such as seagrass-associated fish (Sogard 1984, Klumpp et al. 1989) and larger invertebrates (Briones-Fourzán et al. 2003). In addition, specialized guilds of leaf-boring isopods and polychaetes find shelter, food and microhabitat within the leaf sheaths of certain seagrass species (Gambi et al. 2003). Apart from these influences on the seagrass community 
and ecosystem dynamics, meso-grazers may also interfere with the sexual reproductive cycle of the seagrasses through consumption of seeds, as has been reported for inflorescence-bearing species of the families Zosteraceae and Posidoniaceae. Crustaceans (in addition to molluscs and fish) consume or damage seeds of Zostera marina in Chesapeake Bay, USA (Wigand \& Churchill 1988), the isopod Idotea reseata feeds on seeds of Phyllospadix torreyi in Santa Barbara, USA (Holbrook et al. 2000), and a tanaid isopod bores the seeds of $Z$. marina and $Z$. caulescens in Japan (Nakaoka 2002). More recently, Orth et al. $(2006,2007)$ reported extensive crustacean consumption of seed-bearing inflorescences of Posidonia australis in Western Australia, and Reynolds et al. (2012) suggested that the introduced amphipod Amphithoe valida could potentially remove all seeds in a Californian meadow of $Z$. marina within 1 to $3 \mathrm{wk}$. The present study highlights yet another interaction between seagrasses and meso-grazers, by describing the foraging of small invertebrates on pollen embedded in mucilage of the tropical seagrass Thalassia testudinum.

The dioecious turtle grass Thalassia testudinum releases pollen after sunset. At the onset of night-time, mature male flowers initiate dehiscence, and pollen grains, embedded in a mucilaginous matrix, are released within 1 to $2 \mathrm{~h}$ (Van Tussenbroek et al. 2008, 2009). The synchronized nocturnal flowering may aid to avoid pollen predation by diurnally active parrotfish or may serve to synchronize male and female functions (Van Tussenbroek et al. 2008, 2009, Van Tussenbroek \& Muhlia-Montero in press). However, at dark, the abundance of smaller fauna in the seagrass canopy increases (Heck \& Orth 1980, Bauer 1985, Howard 1987). Small invertebrates usually remain hidden between the leaves, detritus or inside the sediment during the day, and they increase foraging during the night (Kitting 1984). Here we report the identity and abundance of a diverse assemblage of invertebrates that we observed on male flowers in anthesis. We also speculate on the potential role of these invertebrates as pollen predators or pollinators for $T$. testudinum.

\section{MATERIALS AND METHODS}

The study was carried out in Puerto Morelos reef lagoon, Mexico $\left(20^{\circ} 51^{\prime} \mathrm{N}, 86^{\circ} 55^{\prime} \mathrm{W}\right)$. On the seaward side, the lagoon is bordered by a fringing reef, and landwards by a 2 to $5 \mathrm{~m}$ high sandbar. The bottom of the lagoon, generally between 2 and 4 m deep, is covered by a well-developed mixed seagrass com- munity dominated by Thalassia testudinum. At various sites near the reef where flowering frequency was relatively high, male flower buds of $T$. testudinum expected to undergo dehiscence were marked before sunset on 12 and 13 May and 10 June 2009. Video recordings of the flowers were made with standard underwater digital cameras (distance from flower $\sim 10 \mathrm{~cm}$, see video in Supplement 1, available at www.int-res.com/articles/suppl/m469p001_supp/). Open male flowers which had released pollen the previous night were filmed as controls. It was expected that if the invertebrates were attracted to the pollen-mucilage mass, then they would be absent or less abundant on the control flowers. All flowers were illuminated with standard white flash lights. This procedure was repeated for male flowers with pollen and female flowers on 2, 9 and 24 May 2012. The number and time of visits of meso-fauna to each flower were determined from the video clips for 5 haphazardly chosen intervals of 1 min each (between 20:00 and 20:30 h). Pairs of flowers were grouped by date because composition and abundance of visiting fauna may vary among nights. A non-parametric pairwise comparison (Wilcoxon signed rank test) was applied to determine whether the frequency of visits differed between male flowers with or without pollen (2009) or between male flowers bearing pollen and female flowers (2012). A chi-squared analysis was applied to determine whether the duration of the visits (grouped in the following classes: $>0-1 \mathrm{~s},>1-3 \mathrm{~s}$, $>3-6 \mathrm{~s}_{1}>6-9 \mathrm{~s}, \geq 10 \mathrm{~s}$ ) was independent of the type of flower. Each analysis was applied separately for crustaceans and polychaetes.

In addition, the meso-fauna from pollen-bearing male flowers was collected during the nights of 11 May $(\mathrm{n}=11), 20$ May $(\mathrm{n}=21)$ and 10 June $2009(\mathrm{n}=$ $24)$, and on 17 May $2011(n=20)$. Flashlights with red filters were used to search the flowers in order to minimize the effect of photic attraction by the invertebrates. Once a flower was detected, the red light was switched off and a white flashlight was placed at $\sim 1$ to $3 \mathrm{~m}$ distance to distract free-swimming invertebrates from the flower. The red light was switched on again to illuminate the flower and immediately afterwards a clear plastic tube $(50 \mathrm{ml})$ was placed over the flower. The tube was closed with a stopper, and we then broke the pedicel of the flower at the level of the sediment. In the laboratory, after $\sim 1 \mathrm{~h}$ the samples were preserved in $10 \%$ formalin. The following day, the flowers were observed under a binocular microscope and all invertebrates were separated and placed in small vials with alcohol for later identification and quantification. In 2009, a small number of 
male flowers $(n=19)$ which had released pollen the previous night (male without pollen) and female flowers $(n=9)$ were also sampled. Crustaceans and annelids were identified to the lowest possible taxon (Supplement 2, available at www.int-res.com/articles/ suppl/m469p001_supp.pdf).

\section{RESULTS}

Male flowers of Thalassia testudinum bearing pollen were visited by both crustaceans and polychaetes (Fig. 1, see video in Supplement 1). At the beginning of the night, the number of visits of invertebrates to the flowers was low and short in duration (mostly $\leq 1 \mathrm{~s}$, Fig. 2). Visits lasting $\leq 1 \mathrm{~s}$ were mostly by the fauna touching the flower. As the night advanced, crustaceans tended to spend more time on the flowers with pollen and mucilage (Fig. 2), and foraging was obvious (Supplement 1). Visits by crustaceans to male flowers without pollen and to female flowers were significantly less frequent than those to flowers with pollen (Fig. 3, Table 1). Crustaceans spent more time on pollen-bearing male flowers than on those without pollen, but they remained for equal amounts of time on both male flowers with pollen and female flowers (Fig. 3, Table 1). Polychaetes appeared later at night (Fig. 2), and no differences were observed in the frequency or duration of their visits to flowers with or without pollen (Fig. 3, Table 1). Epitokous individuals (those with posterior sexual segments) appeared to bury themselves into the flowers with wriggling movements, while non-reproductive individuals slid along the anthers without pausing.
A large variety of crustaceans was sampled (Table 2 and Supplement 2, available at www.int-res.com/ articles/suppl/m469p001_supp.pdf). Combined samples from 2009 and 2011 (76 flowers) included 252 specimens belonging to 37 families and 57 species distributed among 3 classes (Malacostraca, Maxillopoda and Ostracoda), and 15 species were new records for the region. We recorded 46 species of Malacostraca; these were mainly peracarids, with Isopoda (11 species) and Amphipoda (8 species, dominated by Tethygeneia longleyi) most abundant among them. Within this class, decapods were most diverse (12 species) of which $90 \%$ were at zoea I stage. Hippolythidae and Majidae were the dominant families. Maxillopoda was the second most abundant class (6 species). Fewer Ostracoda were reported, and $71 \%$ of them were represented by Skogsbergia lerneri. Compared to the crustaceans, the annelids (mainly polychaetes) were less abundant and diverse (Table 2 and Supplement 2); 16.4\% of the polychaets belonged to the Alciopidae, a pelagic family, and $47.5 \%$ to the Nereididae. Most nereid polychaetes $(75.8 \%)$ were epitokous.

\section{DISCUSSION}

Due to the hydrodynamic forces (current velocity $\leq 25 \mathrm{~cm} \mathrm{~s}^{-1}$ prevailing in the study area, SanabriaAlcaraz 2009), the arrival of small invertebrates to the flowers was likely aleatory to a certain degree. Invertebrates were swept to and fro by wave movements, but active swimming was observed on occasion as they came near the flowers. The frequency of visits to
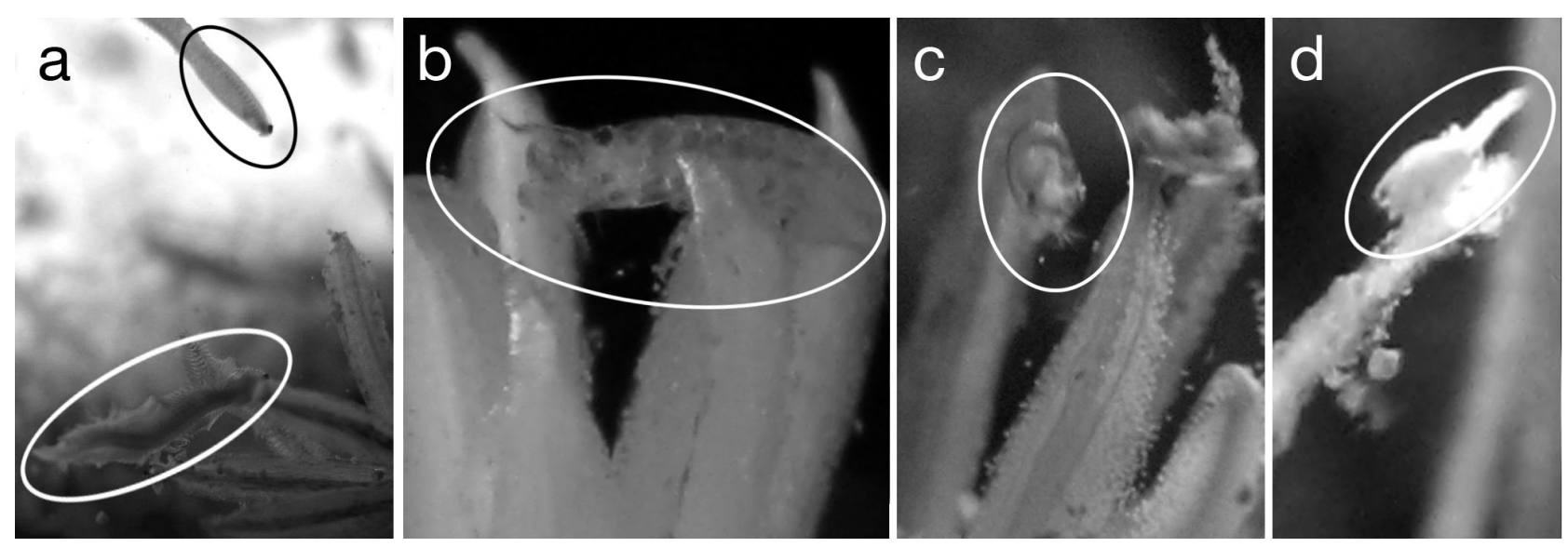

Fig. 1. Thalassia testudinum. Meso-faunal invertebrates on flowers of T. testudinum. (a) Polychaetes approaching a male flower with pollen. (b) Amphipod crustacean feeding on pollen and mucilage. (c) Ostracod crustacean at the moment of detachment from a male anther by wave action. (d) Cumacean crustacean on the stigma of a female flower (see also video in Supplement 1, available at www.int-res.com/articles/suppl/m469p001_supp/) 


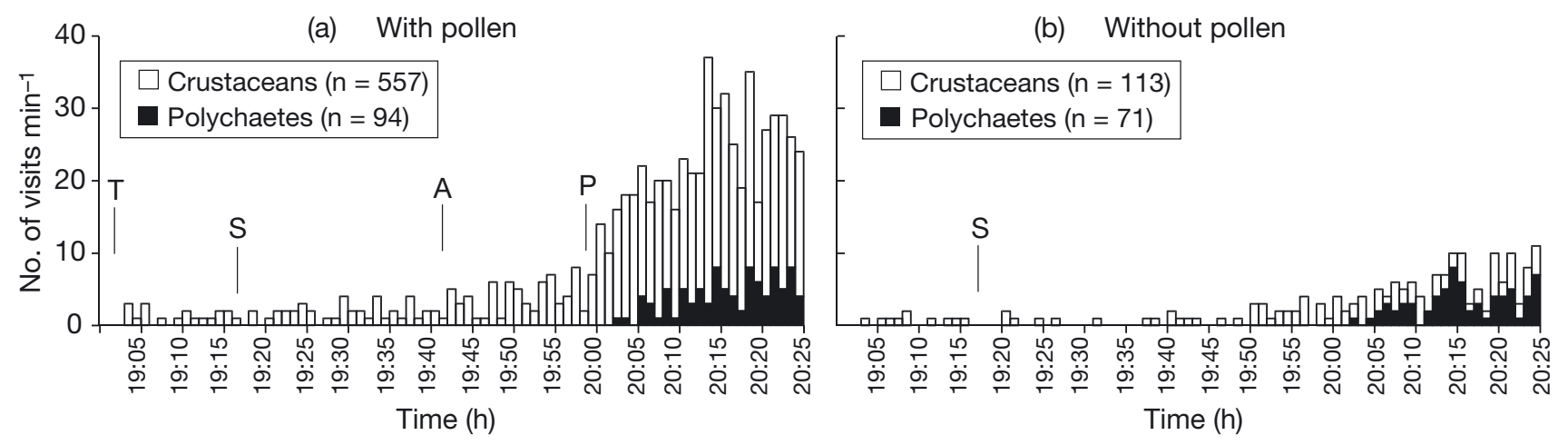

Fig. 2. Thalassia testudinum. Visits of crustaceans and polychaetes to a male flower (a) with pollen and (b) without pollen, registered by videos on 11 May 2009 in Puerto Morelos reef lagoon. The time interval between arrival and departure was measured to the nearest second. T: tepals opening up, S: sunset, A: anthers opening up (initiating release of small masses of pollen and mucilage), $\mathrm{P}$ : onset of copious pollen release. $\mathrm{n}$ : total number of registered visitors to the flowers

the flowers differed among nights (Fig. 3), and the specific composition of the visiting meso-fauna most likely also fluctuated in time, although we did not quantify this. On a daily basis, the frequency of visits by crustaceans to flowers increased as the night advanced, and the first appeared much later than the crustaceans (after 20:00 h in May and June 2009, 2011 and 2012). These sequential arrivals may be
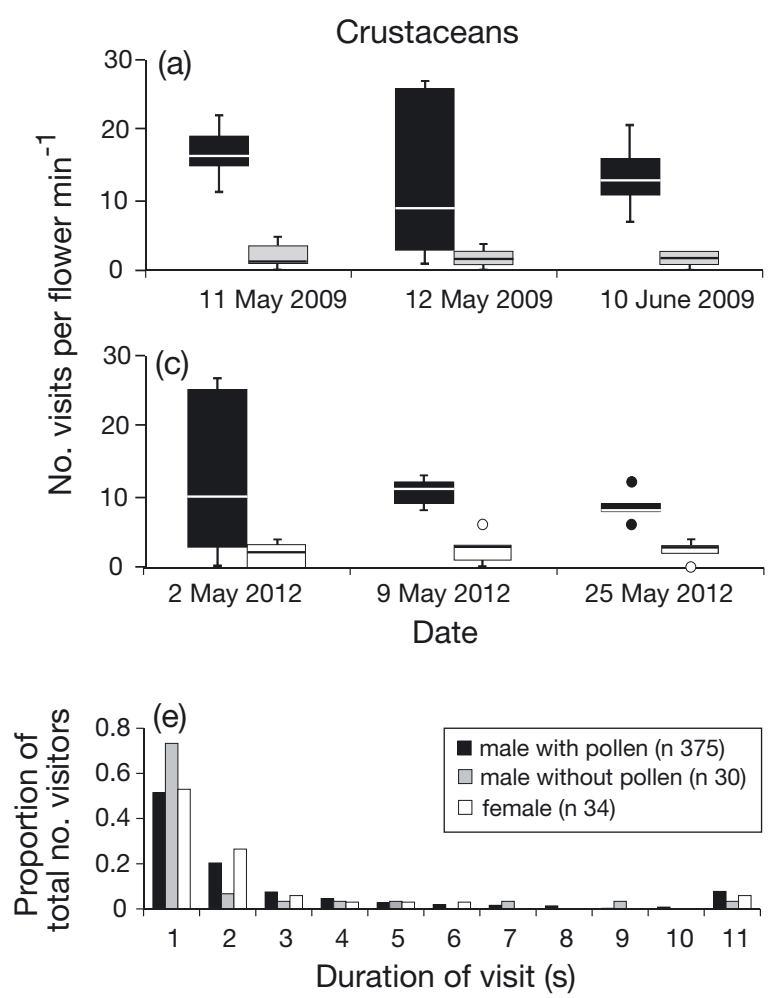

due to internal rhythms of the species or associated with peaks in pollen release of the flowers.

The high diversity of crustaceans visiting the flowers was surprising. This study was exploratory, and the finding that 15 out of 57 observed species were new records for the Mexican Caribbean (Supplement 2) emphasizes our lack of knowledge concerning the faunal biodiversity associated with seagrasses in reef
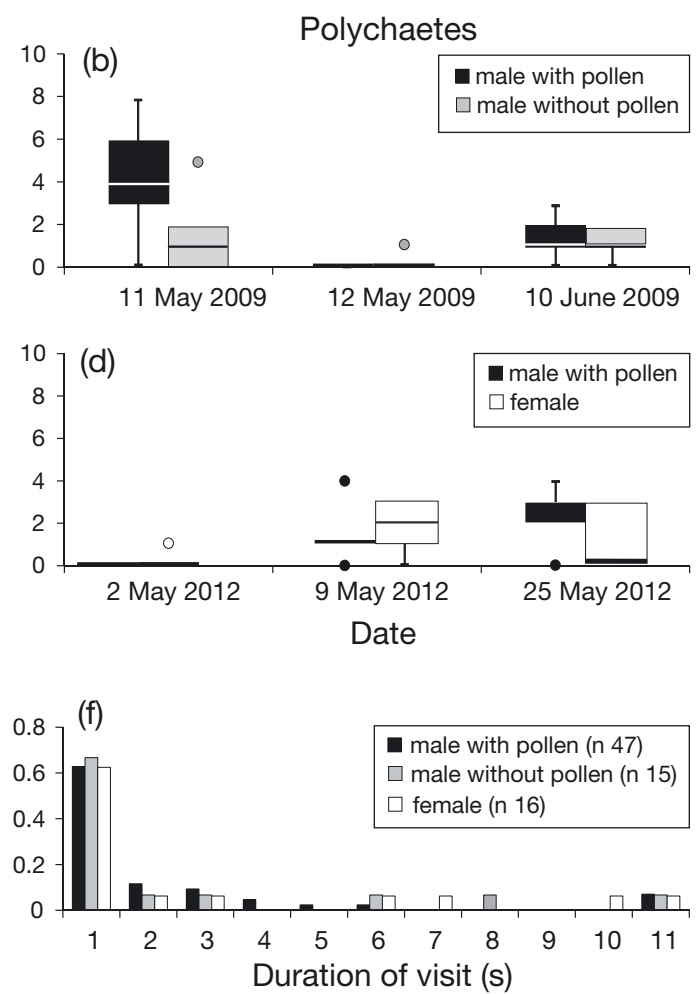

Fig. 3. Thalassia testudinum. (a-d) Number of visits of meso-fauna to flowers of T. testudinum in Puerto Morelos reef lagoon, determined from video clips. Each box shows the median (horizontal bar), 25th and 75th percentiles (box), spread (whiskers) and outliers (dots), and each box represents 1 flower. Visits of crustaceans and polychaetes were determined on the same flowers. Note the difference in ordinate scales for crustaceans and polychaetes. (e, f) Frequency diagrams of the time that visitors spent on flowers. $\mathrm{n}$ : total number of visitors to a given type of flower 
Table 1. Thalassia testudinum. Wilcoxon signed rank test for differences between the number of visits $\min ^{-1}$ of mesofauna to male flowers with $(\mathrm{w})$ and without (w/o) pollen (P) (2009), and to male flowers bearing pollen and female flowers (2012) in Puerto Morelos reef lagoon, Mexico ( $n=15$ paired comparisons). The chi-squared test verified whether the duration of the visits was independent of the type of flower (male with pollen, male without pollen, female), $\mathrm{df}=4$

\begin{tabular}{|c|c|c|c|c|}
\hline \multirow[t]{2}{*}{ Comparison of visits } & \multicolumn{2}{|c|}{$\begin{array}{l}\text { No. } \text { min }^{-1} \\
\text { (Wilcoxon) }\end{array}$} & \multicolumn{2}{|c|}{$\begin{array}{l}\text { Duration } \\
\text { (chi-squared) }\end{array}$} \\
\hline & $Z$ & $\mathrm{p}$ & $\chi^{2}$ & $\mathrm{p}$ \\
\hline \multicolumn{5}{|l|}{ Crustaceans } \\
\hline Male w vs. male w/o P & 3.4 & $<0.001$ & 10.14 & $<0.05$ \\
\hline Male w P vs. female & 3.3 & $<0.001$ & 4.43 & $>0.25$ \\
\hline \multicolumn{5}{|l|}{ Polychaetes } \\
\hline Male w vs. male w/o P & 1.8 & $>0.05$ & 1.6 & $>0.75$ \\
\hline Male w P vs. female & 1.0 & $>0.10$ & 4.4 & $>0.10$ \\
\hline
\end{tabular}

Table 2. Thalassia testudinum. Specific richness of the meso-fauna visiting seagrass flowers in Puerto Morelos reef lagoon during May 2009 and 2011, n = 76 (51 male flowers with pollen, 19 male flowers without pollen and 6 female flowers). In total, 312 meso-faunal specimens were collected. Relative abundance: \% of all specimens found on all flowers. See Supplement 2 (available at www.int-res.com/ articles/suppl/m469p001_supp.pdf) for the species list

\begin{tabular}{|lcc|}
\hline & $\begin{array}{c}\text { No. } \\
\text { species }\end{array}$ & $\begin{array}{c}\text { Relative } \\
\text { abundance (\%) }\end{array}$ \\
\hline Crustaceans & & \\
Class Maxilopoda & & \\
- Copepoda & 6 & 21.2 \\
Class Ostracoda & & \\
- Ostracoda & 5 & 9.0 \\
Class Malacostraca & & 2.6 \\
- Mysidacea & 1 & 17.9 \\
- Amphipoda & 8 & 5.4 \\
- Isopoda & 11 & 3.2 \\
- Cumacea & 10 & 9.6 \\
- Tanaidacea & 4 & \\
- Decapoda & 12 & 17.6 \\
Annelids & & 1.6 \\
Class Polychaeta & 12 & \\
Class Oligochaeta & 1 & \\
\hline
\end{tabular}

lagoons in this region. Information on the dietary preferences of the crustaceans indicated that many were herbivores or omnivores (Supplement 2). Mucilage and pollen of Thalassia testudinum are rich in polysaccharides and proteins (Van Tussenbroek et al. 2009) and are of potential nutritional value. The high intensity of visits by crustaceans to male flowers with pollen suggested that pollen grains or mucilage may serve as a food source. This, if confirmed by subse- quent gut content analyses, makes the present observations the first record of pollen (or its mucilaginous vehicle) consumption by marine meso-fauna. The polychaetes were less abundant and diverse than the crustaceans and were represented by 9 families. The collected species tended to be non-selective and opportunistic feeders (Fauchald \& Jumars 1979), but the epitokous specimens lacked well-formed jaws. The frequency and duration of visits by polychaetes was similar on male flowers with and without pollen, which suggests that they were not feeding. However, the epitokous individuals might have changed the usual feeding habit to suction of the polysaccharideand protein-rich mucilage.

Negative consequences of the pollen consumption for the reproductive success of the seagrass were most likely insignificant. Thalassia testudinum suffered from pollen limitation after experimental reduction of male flowers at this site (Van Tussenbroek et al. 2010). However, the flowers produced a large number of pollen grains (on average $1.6 \times$ $10^{5}$ grains flower ${ }^{-1}$, Van Tussenbroek et al. 2010), and the small invertebrates did not remove substantial quantities of pollen. However, some visitors had sticky mucilage with pollen grains attached to their carapace, legs or segments when removed from the flowers by waves (Supplement 1). Female flowers received the same visitors as male flowers (Supplement 2), and some might have carried some pollen grains (Supplement 1). Buschmann \& Santelices (1987) and Buschmann (1991) studied grazing by the amphipod Hyale hirtipalma on cystocarpic tissues of the red algae Iridaea laminarioides (now Mazzaella laminarioides). During feeding, the amphipod tore the cystocarps, releasing spores into the water column, with some spores sticking to the legs of the amphipods and fractions of the ingested spores surviving passage through the amphipod digestive tract. Thus the amphipods may disperse the carpospores of the alga. In a similar way, the small invertebrates observed in this study may serve as pollinators of $T$. testudinum, which could be especially significant under conditions of calmer waters and reduced flowering frequency, when the possibilities of hydrophilous pollination are reduced. The range of motility of these small organisms might exceed that of the passive transport of pollen grains by water movements, which was usually $\leq 1 \mathrm{~m}$ in the study area (Sanabria-Alcaraz 2009, Van Tussenbroek \& MuhliaMontero in press). Thus, our study suggests that the multiple interactions between meso-fauna and seagrasses may also include pollen consumption and possibly even pollination. 
Acknowledgements. This work was funded by the Instituto de Ciencias del Mar y Limnología, Universidad Nacional Autónoma de México (UNAM), and project no. 82724 (CB2007-1, CONACyT). The help of M.G. Barba Santos, R. Wong, F. Negrete, C. Barradas and A.Y. Pérez Mendoza is greatly appreciated. We thank L. Harris for early identifications of some of the polychaetes. We also thank the anonymous reviewers and K. L. Heck for comments and suggestions to improve the original version of the manuscript.

\section{LITERATURE CITED}

Bauer TR (1985) Diel and seasonal variation in species composition and abundance of caridean shrimps (Crustacea, Decapoda) from seagrass meadows on the north coast of Puerto Rico. Bull Mar Sci 36:150-162

Briones-Fourzán P, Castañeda-Fernández de Lara V, LozanoÁlvarez E, Estrada-Olivo J (2003) Feeding ecology of the three juvenile phases of the spiny lobster Panulirus argus in a tropical reef lagoon. Mar Biol 142:855-865

Buschmann AH (1991) Amphipod food preference and Iridaea spp. (Rhodophyta) spore release and dispersal. J Mar Biol Assoc UK 71:891-897

Buschmann AH, Santelices B (1987) Micrograzers and spore release in lridaea laminarioides Bory (Rhodophyta: Gigartinales). J Exp Mar Biol Ecol 108:171-179

Duffy JE, Hay ME (2000) Strong impacts of grazing amphipods on the organization of a benthic community. Ecol Monogr 70:237-263

Fauchald K, Jumars P (1979) The diet of worms: a study of polychaete feeding guilds. Oceanogr Mar Biol Annu Rev 17:193-284

Gambi MC, Van Tussenbroek BI, Brearley A (2003) Mesofaunal borers in seagrasses: world-wide occurrence and a new record of boring polychaetes in the Mexican Caribbean. Aquat Bot 76:65-77

Heck KL Jr, Orth R (1980) Structural components of eelgrass (Zostera marina) meadows in the lower Chesapeake Bay-decapod crustacea. Estuaries 3:289-295

Holbrook SJ, Reed DC, Hansen K, Blanchette CA (2000) Spatial and temporal patterns of predation on seeds of the surfgrass Phyllospadix torreyi. Mar Biol 136:739-747

Howard RK (1987) Diel variation in the abundance of epifauna associated with seagrasses of the Indian River, Florida, USA. Mar Biol 96:137-142

Jernakoff P, Brearley A, Nielsen J (1996) Factors affecting grazer-epiphyte interactions in temperate seagrass meadows. Oceanogr Mar Biol Annu Rev 34:109-162

Kitting CL (1984) Selectivity by dense populations of small invertebrates foraging among seagrass blade surfaces. Estuaries 7:276-288

Editorial responsibility: Hans Heinrich Janssen, Oldendorf/Luhe, Germany
Klumpp DW, Howard RK, Pollard DW (1989) Trophodynamics and nutritional ecology of seagrass communities. In: Larkum AWD, McComb AJ, Shepherd SA (eds) Biology of seagrasses. A treatise on the biology of seagrasses with special reference to the Australian region. Elsevier, Amsterdam, p 394-457

> Nakaoka M (2002) Predation on seeds of seagrasses Zostera marina and Zostera caulescens by a tanaid crustacean Zeuxo sp. Aquat Bot 72:99-106

> Nienhuis PH, Van Ierland ET (1978) Consumption of eelgrass, Zostera marina, by birds and invertebrates during the growing season in Lake Grevelingen (SW Netherlands). Neth J Sea Res 12:180-194

Orth RJ, Van Montfrans J (1984) Epiphyte-seagrass relationships with an emphasis on the role of micrograzing: a review. Aquat Bot 18:43-69

> Orth RJ, Kendrick GA, Marion SR (2006) Predation on Posidonia australis seeds in seagrass habitats of Rottnest Island, Western Australia: patterns and predators. Mar Ecol Prog Ser 313:105-114

Orth RJ, Kendrick GA, Marion SR (2007) Posidonia australis seed predation in seagrass habitats of Two Peoples Bay, Western Australia. Aquat Bot 86:83-85

Reynolds LK, Carr LA, Boyer KE (2012) A non-native amphipod consumes eelgrass inflorescences in San Francisco Bay. Mar Ecol Prog Ser 451:107-118

Sanabria-Alcaraz SNM (2009) Rango de dispersión del polen de Thalassia testudinum en la laguna arrecifal de Puerto Morelos. BS honours dissertation, Universidad Nacional Autónoma de México, Mexico City

Sogard SM (1984) Utilization of meiofauna as a food source by a grassbed fish, the spotted dragonet Callionymus pauciradiatus. Mar Ecol Prog Ser 17:183-191

Van Tussenbroek BI, Muhlia-Montero M (in press) Can floral consumption by fish shape traits of seagrass flowers? Evol Ecol (EVEC-D-12-00018)

> Van Tussenbroek BI, Wong JGR, Márquez-Guzmán J (2008) Synchronized anthesis and predation on pollen in the marine angiosperm Thalassia testudinum (Hydrocharitaceae). Mar Ecol Prog Ser 354:119-124

Van Tussenbroek BI, Márquez-Guzmán J, Wong R (2009) Phenology of marine angiosperms (seagrasses): reproductive synchrony in the sea. In: Pandalai SG (ed) Functional approach to sexual plant reproduction. Research Signpost, Trivandrum, p 17-46

> Van Tussenbroek BI, Muhlia-Montero M, Wong R, BarbaSantos MG, Márquez-Guzmán J (2010) Pollen limitation in a dioecious seagrass: evidence from a field experiment. Mar Ecol Prog Ser 419:283-288

> Wigand C, Churchill AC (1988) Laboratory studies on eelgrass seed and seedling predation. Estuar Coasts 11: 180-183

Submitted: April 12, 2012; Accepted: September 25, 2012 Proofs received from author(s): October 26, 2012 